\title{
IJBAR NIKAH DI KAMPUNG SIDOSERMO DALAM SURABAYA PERSPEKTIF HUKUM ISLAM
}

\author{
Abdulloh Faqih Putro \\ Argo \\ UIN Sunan Ampel \\ Surabaya \\ faqihputraargo@gmail.com

\section{Mokhammad Rizky Khoirul Amin} \\ UIN Sunan Ampel \\ Surabaya \\ rizky28amin@gmail.com

\section{Muh Nurkholis} \\ UIN Sunan Ampel \\ Surabaya \\ muhnurkholis3@gmail.com
}

Abdul Rouf
UIN Sunan Ampel
Surabaya
gusdol755@gmail.com
Nur Lailatul Musyafa'ah
UIN Sunan Ampel
Surabaya
nurlailatul@uinsby.ac.id

\begin{abstract}
This article discusses about the forced marriage in Sidosermo Dalam Surabaya to be analyzed by Islamic law. This research is field research and is qualitative in nature. Data were collected through interviews and documentation, then analyzed deductively. The forced marriage still occurs in Sidosermo Dalam Surabaya. Marriage was motivated by several reasons: the factor of parents' concern for their child, the factor of family relations, the existence of myths, the existence of Syafii's understanding of fiqh that allows the forced marriage, and economic factors. The forced marriage can occur in girls and boys even though they are adults. In Islamic law, all schools of thought think that the permissible marriage permit is for girls who are not yet mature, while for those who are adults or who are widows there is a dispute between the imam of the mazhab. In the KHI, the forced marriage should not occur because the marriage can be carried out with the consent of the two prospective brides.
\end{abstract}

Keywords: Ijbar nikah, Islamic law, and Sidosermo Dalam

\begin{abstract}
Abstrak: Artikel ini membahas tentang ijbar nikah di Sidosermo Dalam Surabaya untuk dianalisis dengan hukum Islam. Penelitian ini adalah penelitian lapangan dan bersifat kualitatif. Data dikumpulkan melalui wawancara dan dokumentasi, kemudian dianalisis secara deduktif. Ijbar nikah masih terjadi secara masif di Kampung Sidosermo Dalam Surabaya. Perkawinan itu dilatarbelakangi oleh beberapa sebab, yaitu faktor kekhawatiran orang tua terhadap anaknya, faktor hubungan keluarga, adanya mitos, dan adanya pemahaman fikih Syafii yang membolehkan ijbar nikah. Ijbar nikah tersebut bisa terjadi pada anak perempuan dan laki-laki meski sudah dewasa. Dalam hukum
\end{abstract}




\section{Pendahuluan}

Islam, semua mazhab berpendapat bahwa ijbar nikah yang diperkenankan adalah kepada anak perempuan yang belum dewasa, sedangkan yang sudah dewasa atau yang janda terdapat perselisihan di antara imam mazhab. Dalam KHI, ijbar nikah tidak semestinya terjadi karena pernikahan bisa dilakukan dengan persetujuan dari kedua calon mempelai.

Kata Kunci: ijbar nikah, hukum Islam, dan Sidosermo Dalam

Ijbar nikah atau kawin paksa pada dasarnya tidak diakui dalam Undang-Undang Perkawinan dan KHI (Kompilasi Hukum Islam). Dalam pasal 6 ayat (1) Undang-Undang Perkawinan maupun pasal 16 ayat (1) KHI disebutkan bahwa: perkawinan harus didasarkan atas persetujuan kedua caon mempelai. Namun peluang adanya kawin paksa ini dimungkinkan oleh kedua aturan ini, yakni dalam Undang-Undang Perkawinan melalui institusi pemberian izin dari orang tua kepada anak yang hendak kawin yang belum berusia 21 tahun (pasal 6 ayat (2) dan dalam KHI melalui bentuk persetujuan calon mempelai wanita, yang dikatakan dalam pasal 16 ayat (2), bahwa: "Bentuk persetujuan calon mempelai wanita dapat berupa pernyataan tegas dan nyata dengan tulisan, lisan atau isyarat, tapi dapat juga berupa diam, dalam arti selama tidak ada penolakan yang tegas." 1

Perwalian berasal dari kata wali yang mempunyai arti orang lain selaku pengganti orang tua, yang menurut hukum diwajibkan mewakili anak yang belum dewasa atau belum akil balig dalam melakukan perbuatan hukum. Menurut Pasal 1 huruf $\mathrm{h}$ KHI, perwalian adalah kewenangan yang diberikan kepada seseorang untuk melakukan sesuatu perbuatan hukum sebagai wakil untuk kepentingan dan atas nama anak yang tidak

1 Ratna Batara Munti and Hindun Anisah, Posisi Perempuan dalam Hukum Islam di Indonesia (Jakarta: LBH-APIK, 2005), 60-61. 
mempunyai kedua orang tua, atau kedua orang tua masih hidup tetapi tidak cakap melakukan perbuatan hukum.2

Menurut Wahbah al-Zuhaili perwalian adalah orang dewasa yang memiliki kesempurnaan berpikir diberi kuasa melaksanakan perkara orang lain yang belum dianggap dewasa dalam hal transaksi harta atau pemenuhan hak dan kewajiban personal.3 Dalam pernikahan, istilah wali terbagi menjadi dua, pertama; wali mujbir, yaitu wali yang berhak untuk menikahkan orang yang dalam perwaliannya tanpa persetujuan dari pihak yang bersangkutan, kedua; wali ghair mujbir, yaitu wali yang tidak memiliki hak memaksa kepada yang diwalikan dan tidak memiliki hak menikahkan tanpa persetujuan calon mempelai.4 Hal ini menjadi sebuah problema klasik bahwa wali mujbir dapat memaksa orang lain untuk melakukan sebuah perintah tanpa persetujuan yang bersangkutan.

Konsep pemaksaan dalam Islam berhubungan dengan hal yang wajib, seperti pemaksaan pemenuhan hutang, 5 pembayaran zakat, pembayaran jizyah (pajak) untuk penduduk non-muslim, 6 yang menjadi hak secara legal dalam Islam oleh pemerintah atau pemaksaan secara individu seperti pemaksaan dalam akad shuf'ah,7 dan pemaksaan orang tua terhadap anak dalam melakukan shalat dan lain sebagainya. 8

2 Ishak, "Perwalian Menurut Konsep Hukum Tertulis," Kanun Jurnal Ilmu Hukum, Vol. 19, No. 3 (Desember, 2017), 573.

3 Wahbah Al-Zuhaily, Al-Fiqh al-Islamy wa Adillatuh, Juz VII (Beirut: Dar alFikr, 1998), 7.

4 Taufiq Hidayat, "Rekonstruksi Konsep Ijbar," De Jure, Jurnal Syariah dan Hukum, Vol. I, No. 1 (Juni, 2009), 10-22.

5 Ady Cahyadi, "Mengelola Hutang dalam Perspektif Islam," ESENSI: Jurnal Bisnis dan Manajemen, Vol. 4, No. 1, (Juni, 2014), 76.

6 Gampito, "Pemikiran Kebijakan Fiskal Ekonomi Islam," Juris: Jurnal Ilmu Syariah, Vol. 9, No. 1 (Juni, 2010), 32-46.

7 Muhamad Masrur, “Konsep Harta dalam Al-Qur'an dan Hadis," Jurnal Hukum Islam, Vol. 15, No. 1, (Juni, 2017), 112.

8 Heru Sada Juabdin, "Konsep Pembentukan Kepribadian Anak dalam Perspektif Al-Qur'an (Surat Luqman Ayat 12-19)," Al-Tadzkiyyah: Jurnal Pendidikan Islam, Vol. 6, No. 2, (November, 2015), 253-72. 
Konsep perwalian dalam ijbar nikah menjadi perdebatan di antara ulama, baik salaf maupun ulama modern. Dari kalangan Mazhab Maliki berpendapat bahwa hak kewenangan ijbar hanya boleh dilakukan oleh seorang ayah saja, selain ayah baik kakek, saudara, paman, dan yang lainnya tidak dapat memaksa seorang wanita untuk menikah.9 Hak ijbar dalam pandangan Mazhab Maliki hanya untuk wanita yang masih kecil, baik masih berstatus perawan ataupun sudah bersetatus janda,10 dan wanita dewasa yang masih perawan saja,11 sedangkan janda yang sudah dewasa tidak dapat untuk dipaksa meskipun oleh seorang ayahnya.

Dalam pandangan Mazhab Shafi'i wanita yang dapat dipaksa menikah adalah seorang wanita yang masih dalam status perawan, baik sudah dewasa ataupun masih kecil, sedangkan wanita yang sudah berstatus janda, baik masih kecil ataupun sudah dewasa maka tetap harus dimintakan izinnya dan pernyataan izin darinya secara șārih.12 Dalam mazhab Shafi'i, ijbar nikah hanya berlaku bagi ayah dari wanita tersebut dan juga kakeknya jika sang ayah sudah wafat atau tidak ada, 13 sedangkan menurut Mazhab Hambali ijbar nikah boleh dilakukan terhadap wanita kecil yang masih berstatus perawan dengan syarat menikahkannya dengan seorang yang sepadan atau kufu, sedangkan jika wanita kecil itu berstatus janda maka terdapa't dua pendapat di kalangan Mazhab Hambali; pendapat yang mengatakan boleh adalah Ibn Hamid dan al-Kharaqi, pendapat yang tidak memperbolehkan adalah pendapat Imam Abu Bakar dan Abdul Aziz.14 Untuk wanita yang dewasa maka

\footnotetext{
9 Musthafa Dib Al-Bugha, Al-Tadzhīb Fi Adillati Matn al-Ghāyah Wa al-Taqrīb (Beirut: Dār Ibn Katsir, 1992), 47.

10 Ibn Rusyd, Bidāyah Al-Mujtahid Wa Nihāyah al-Muqtașid, Juz II (Kairo: Maktabah Ibnu Taimiyah, 1994), 45.

11 Abdul Wahab Bin Ali Al-Baghdadi, Ishrāf 'Ala Nuqāt Masā'il al-Khilāf (Beirut: Dār Ibn Hazm, 1999), 87.

12 Yahya bin Syaraf Al-Nawawi, Minhāj al-Talibin Wa 'Umdah al-Muftīn (Beirut: Dār al-Fikr, 1992), 206.

13 Ibid, 206

14 Ibn Qudamah, Al-Mughnī, Juz 7 (Kairo: Dār al-Manār, 1999), 279.
} 
jika dia berstatus janda maka tidak diperbolehkan untuk dipaksa dalam pernikahan, jika dia berstatus perawan maka terdapat dua pandangan di kalangan Mazhab Hambali, pertama; boleh untuk memaksanya, pendapat ini dipilih oleh Ibn Abi Laila dan Ishaq, kedua pendapat yang mengatakan tidak boleh dipilih oleh Abu Bakar, Imam Auza'i, Ibn Mundzir dan beberapa ulama lainnya.15

Dalam Mazhab Hanafi pendapat tentang masalah ijbar nikah lebih menekankan pada kedewasaan seseorang. Jika seorang anak itu dewasa atau sudah balig maka orang tua tidak boleh memaksa seorang anak untuk menikah.16 Hal ini lebih berlaku baik dia berstatus perawan atau janda, kebolehan memaksa nikah hanya berlaku jika seorang anak masih kecil atau belum balig dan bukan berstatus janda,17 jadi dalam pandangan mazhab Hanafi pemaksaan hanya berlaku pada seorang anak yang masih kecil. Adapun gadis yang tidak memiliki kesempurnaan akal atau gila, baik dewasa ataupun tidak, maka dalam hal ini disamakan dengan status anak yang masih kecil.

Kampung Sidosermo Dalam merupakan sebuah kampung di Surabaya yang terdapat banyak pesantren. Meskipun di Indonesia terdapat aturan yang melarang ijbar nikah, namun di Sidosermo Surabaya masih terdapat tradisi ijbar nikah, karena berbagai macam faktor. Berdasarkan hal tersebut penulis tertarik membahas tentang praktik ijbar nikah yang terjadi di Kampung Sidosermo Dalam Surabaya yang kemudian dianalisis dengan hukum Islam.

Terdapat beberapa kajian tentang ijbar nikah baik hasil dari penelitian lapangan maupun kepustakaan. Di antara penelitian lapangan yang berkaitan dengan ijbar nikah adalah skripsi Moh Yusuf yang berjudul Tinjauan Hukum Islam terhadap Kawin Paksa dan Implikasi Hukumnya (Studi Kasus di Desa Dekat

15 Ibn Qudamah, Sharh Al-Kabīr (Beirut: Dār al-Fikr, 1998).

16 Abdullah bin Mahmud Mushalli, Al-Ikhtiyār Li Ta'dīl al-Mukhtār, Juz III (Beirut: Dār al-Ma'rifah, 2002), 115.

17 Al-Kasāni, Badāi' al-Sanāi' (Beirut: Dār al-Ihya', 1998), 504. 
Agung Kecamatan Sangkapura Bawean Kabupaten Gresik),18 Skripsi Ammar Siddik Hasibuan dengan judul Otoritas Orang Tua dalam Memaksa Kawin Anak Usia 21 Tahun Ditinjau dari Kompilasi Hukum Islam (Studi Kasus Desa Sibual-buali. Kec. Ulu Barumun, Kab. Palas),19 dan skripsi yang ditulis Samsidar dengan judul Dampak Kawin Paksa terhadap Kehidupan Rumah tangga pada Masyarakat Lamurukung Kabupaten Bone.20 Berdasarkan Penelitian lapangan tersebut belum ada penelitian tentang ijbar nikah di Kampung Sidosermo Dalam Surabaya.

Adapun penelitian pustaka tentang ijbar nikah yang dianalisis dengan berbagai pendekatan di antaranya adalah artikel jurnal yang berjudul Hak Ijbar Wali Nikah dalam Kajian Historis Fiqh Syafi'i yang ditulis Syaiful Hidayat,21 tulisan Arini Robbil Izzati yang berjudul Kuasa Hak Ijbar Terhadap Anak Perempuan Perspektif Fiqh dan HAM,22 tulisan Husnul Haq yang berjudul Reformulasi Hak Ijbar Fiqh dalam Tantangan Isu Gender Kontemporer,23 dan Muhammad Ngizzul Muttaqin dan Nur Fadhilah yang menulis tentang Hak Ijbar Wali Tinjauan

18 Moh Yusuf, "Tinjauan Hukum Islam Terhadap Kawin Paksa dan Implikasi Hukumnya (Studi Kasus di Desa Dekat Agung Kecamatan Sangkapura Bawean Kabupaten Gresik)” (UIN Sunan Ampel Surabaya, 2016).

19 Ammar Hasibuan Siddik, "Otoritas Orang Tua dalam Memaksa Kawin Anak Usia 21 Tahun Ditinjau dari Kompilasi Hukum Islam (Studi Kasus Desa Sibual-Buali. Kec. Ulu Barumun, Kab. Palas)" (Universitas Sumatera Utara, 2018).

20 Samsidar, "Dampak Kawin Paksa Terhdapa Kehidupan Rumah Tangga Pada Masyarakat Lamurukung Kabupaten Bone," Supremasi: Jurnal Pemikiran dan Penelitian Ilmu-Ilmu Sosial, Hukum, \& Pengajarannya, Vol. 14 No. 1 (April, 2019), 21-31.

21 Syaiful Hidayat, "Hak Ijbar Wali Nikah dalam Kajian Historis Fiqh Syafi'i," Tafaqquh: Jurnal Penelitian dan Kajian Keislaman 3, Vol. 3 No. 1 (Juni, 2015), $1-13$.

22 Arini Robbi Izzati, "Kuasa Hak Ijbar Terhadap Anak Perempuan Perspektif Fiqh Dan HAM," Al-Mawarid XI, Vol. 11 No. 2 (September-Januari, 2011), 24154.

23 Husnul Haq, "Reformulasi Hak Ijbar Fiqh dalam Tantangan Isu Gender Kontemporer," Palastren, Vol. 8 no. 1 (Juni, 2015), 197-224. 
Maqashid Syari'ah dan Antropologi Hukum Islam.24 Selain itu, terdapat penelitian tentang perkawinan di Sidosermo yang ditulis Rohmat Hidayatulloh berjudul Tradisi Pernikahan dengan Kesetaraan Keturunan dalam Keluarga Para Mas Sidosermo Kecamatan Wonocolo Surabaya dan Berbek Kecamatan Waru Sidoarjo.25 Dari beberapa penelitian di atas, posisi penelitian ini merupakan penelitian lanjutan dari penelitian tersebut dengan mengkaji praktik ijbar nikah di Kampung Sidosermo Dalam Surabaya.

Penelitan ini adalah penelitian lapangan dan bersifat kualitatif. Data diperoleh langsung dari lapangan baik berupa observasi atau yang berupa hasil wawancara tentang ijbar nikah dalam pemahaman masyarakat Kampung Sidosermo Dalam Surabaya. Dalam hal ini, peneliti mengadakan wawancara kepada 4 orang yang dipaksa kawin, 4 orang tua dari anak yang dipaksa kawin, 3 orang tokoh masyarakat Kampung Sidosermo Dalam Surabaya. Data yang terkumpul dianalisis dengan pola pikir deduktif.

\section{Kerangka Umum tentang Ijbar Nikah}

Ijbar berarti pemaksaan, berasal dari kata paksa yaitu mengerjakan sesuatu yang diharuskan walaupun tidak mau.26 Pemaksaan berarti memaksa seseorang untuk melakukan sesuatu yang tidak dia inginkan dan dia benci dalam arti melakukan sesuatu yang tidak disukai yang dibenci dan didasarkan atas paksaan seseorang.

Dasar ijbar nikah, menurut mazhab Maliki, Syafi'i, dan Hambali adalah unsur status perawan, sehingga meskipun seorang gadis ini sudah dewasa tetapi belum pernah menikah,

24 Muhammad Ngizzul Muttaqin dan Nur Fadhilah, "Hak Ijbar Wali Tinjauan Maqashid Syari'ah dan Antropologi Hukum Islam," Journal de Jure, Vol 12, No. 1 (2020): 102-19.

25 Rohmat Hidayatulloh, "Tradisi Pernikahan dengan Kesetaraan Keturunan dalam Keluarga Para Mas Sidosermo Kecamatan Wonocolo Surabaya dan Berbek Kecamatan Waru Sidoarjo," Al-Hukama', Vol. 7, No. 1 (Juni, 2017), 2650.

26 “Kamus Besar Bahasa Indonesia (KBBI)” (https://kbbi.web.id/paksa, n.d.). 
maka hak ijbar boleh diterapkan. Hal tersebut didasarkan pada hadis:

1. Nabi Muhammad SAW bersabda: "Seorang janda lebih berhak atas dirinya daripada seorang walinya, sedangkan seorang perawan dimintakan persetujuan, diamnya adalah bentuk izinnya." 27

2. Nabi SAW bersabda: Seorang janda tidak boleh dinikahkan kecuali dengan izinnya, dan seorang perawan dimintakan izinnya. Sahabat bertanya: Wahai Rasulullah bagaimana dia memberikan izin? Nabi menjawab: Dengan diamnya.28

Mazhab Hanafi dan satu pendapat di kalangan Malikiah berpendapat bahwa ijbar nikah bergantung pada unsur kedewasaan, sehingga ketika seorang anak sudah dewasa baik masih berstatus perawan ataupun sudah berstatus janda hak ijbar dari ayah sudah tidak lagi boleh diterapkan. Hal tersebut didasarkan pada hadis:

1. Diriwayatkan dari Ibnu Abbas bahwasanya Nabi Muhammad SAW bersabda: Tidak berhak bagi seorang wali memerintah seorang janda untuk menikah, dan gadis dewasa dimintakan persetujuannya, dan diamnya adalah sebuah penerimaan.29

2. Khansa' binti Khidzam dari golongan Anshar menikahkan putrinya yang berstatus janda tetapi putrinya tidak menyetujuinya, dan perempuan itu datang kepada Nabi Muhammad SAW dan beliau bersabda; bahwasanya nikahnya tidak sah.30

Berikut pandangan ijbar nikah menurut imam mazhab:

1. Ijbar nikah menurut Mazhab Maliki

Dalam pandangan mazhab Maliki, masalah ini ada beberapa kasus: Pertama: Ayah bisa memaksa anak yang sudah dewasa untuk menikah, bahkan jika ini bertentangan dengan pendapat anak itu. Dalil untuk pendapat ini adalah hadis Nabi: "Anak yatim berhak dalam dirinya sendiri."

27 Muslim, Sahịh Muslim, n.d., Hadis Nomor 2638.

28 Ibid, Hadis Nomor 1419.

29 Muhammad Abdurrauf Al-Munāwi, Faidh Al-Qadīr Sharh "ala al-Jāmi' alSaghīr, Juz 5 (Beirut: Dār al-Fikr, 2002), 379.

30 Al-Bukhari, Șaḥih Al-Bukhāri, n.d., 4862. 
Berdasarkan mafhum mukhalafah, hadis itu menunjukkan bahwa selain anak yatim bisa dipaksakan untuk sebuah pernikahan karena secara tekstual hadis tersebut menyebutkan hanya anak yatim yang berhak atas dirinya. Kedua, seorang ayah diperbolehkan memaksa pernikahan janda yang masih kecil. Hal ini didasarkan pada hadis yang umum bahwa ketika seorang anak itu masih kecil maka masih dapat untuk dipaksa. Ketiga, anak yang berstatus janda tidak dapat dipaksa menikah. Anak yang berstatus janda yaitu yang telah hilang keperawanannya baik disebabkan bersetubuh dalam pernikahan yang sah atau persetubuhan subhat, atau sebab perbudakan dan bukan karena zina, maka ia tidak bisa dipaksa untuk menikah. Anak perawan memiliki rasa malu yang tinggi dan ketika sudah menikah dengan pernikahan yang sah dan sudah melakukan persetubuhan, maka rasa malu itu sudah berubah sehingga dia memiliki hak untuk tidak dipaksa dan dia sudah bisa menentukan dan memilih yang terbaik untuk dirinya sendiri.

2. Ijbar nikah menurut Mazhab Shafi'i

Wanita yang dapat dipaksa menikah adalah seorang wanita yang masih dalam status perawan baik sudah dewasa ataupun masih kecil, sedangkan seorang wanita yang sudah berstatus janda baik masih kecil ataupun sudah dewasa maka tetap harus dimintakan izinnya dan pernyataan izin darinya secara șārih. Pemaksaan ini dalam mazhab Shafi'i berlaku hanya oleh ayah dari wanita tersebut dan juga kakeknya jika sang ayah sudah wafat atau tidak ada. 31

3. Ijbar nikah menurut mazhab Hambali

Ijbar nikah boleh dilakukan terhadap wanita kecil yang masih berstatus perawan dengan syarat menikahkannya dengan seorang yang sepadan atau kufu'.32 Wanita dewasa yang berstatus janda tidak boleh dipaksa menikah. Jika dia berstatus perawan maka terdapat dua pandangan di kalangan mazhab Hambali, pertama; boleh untuk memaksanya, pendapat ini dipilih oleh Ibn Abi Laila dan

31 Al-Nawāwī, Minhāj al-Ṭalibin Wa 'Umdah al-Muftīn, 206.

32 Qudāmah, Al-Mughnī, 279. 
Ishaq, kedua pendapat yang mengatakan tidak boleh dipilih oleh Abu Bakar, Imam Auza'i, Ibn Mundzir dan beberapa ulama lainnya.33

4. Ijbar nikah menurut Mazhab Hanafi

Orang tua tidak boleh memaksa seorang anak yang sudah baligh untuk menikah,34 baik dia berstatus perawan atau janda. Kebolehan memaksa nikah hanya berlaku jika seorang anak masih kecil atau belum balig dan bukan berstatus janda. ${ }^{6}$

5. Ijbar nikah menurut Mazhab Zhahiri

Seorang perempuan tidak dapat dipaksa untuk menikah jika sudah baligh, baik dia masih berstatus perawan atau sudah berstatus janda tetap tidak diperbolehkan untuk dipaksa menikah. Ungkapan dari Ibnu Hazm yang mengatakan bahwa ketika seseorang perempuan itu sudah mencapai usia baligh baik berstatus perawan atau berstatus janda maka bagi seorang ayah ataupun orang lain tidak diperbolehkan menikahkannya kecuali dengan izin darinya, dan ketika dia dipaksa untuk menikah maka pernikahan itu menjadi sebuah pernikahan yang tidak sah selamanya.

Dari sudut pandang hukum positif di Indonesia hukum pernikahan diatur Dalam Undang-Undang Nomor 1 Tahun 1974, atau yang sudah dikodifikasi dalam KHI, dalam undang-undang ini pernikahan adalah atas dasar persetujuan, sebagaimana dalam Undang-undang KHI Pasal 16 ayat (1) Undang-Undang Nomor 1 Tahun 1974, tentang Perkawinan yang menyatakan bahwa: "Perkawinan harus didasarkan atas persetujuan kedua calon mempelai”. Apabila pernikahan yang dilaksanakan tidak berdasarkan pada unsur persetujuan pihak mempelai maka pernikahan tersebut tidak dapat dilaksanakan dan tidak dianggap sah atau dapat dikatakan batal, sebagaimana dalam pasal 17 Undang-undang nomor 1 tahun 1974 tentang perkawinan: "Bila ternyata perkawinan tidak disetujui oleh salah seorang calon mempelai maka perkawinan itu tidak dapat dilangsungkan". Dalam pasal 71 poin F yang menyebutkan:

33 Qudamah, Syarh Al-Kabir, 113.

34 Mushalli, Al-Ikhtiyar Li Ta'dil al-Mukhtar, Juz 3, 115. 
"Suatu perkawinan dapat dibatalkan apabila perkawinan yang dilaksanakan dengan paksaan".

\section{Sekilas tentang Kampung Sidosermo Dalam Surabaya}

Kampung Sidosermo Dalam sebenarnya memiliki dua nama yaitu Sidosermo dan Sidoresmo, di mana kedua desa ini juga berada di dua Kecamatan yang berbeda pembatas dari dua Kecamatan Wonokromo dan Wonocolo di desa ini adalah sebuah masjid yang bernama masjid Ali Akbar Sidoresmo berada ada di Kecamatan Wonokromo sedangkan Sidosermo berada di Kecamatan Wonocolo.

Secara geografis, kampung ini memiliki batas-batas wilayah diantaranya:

1. Untuk batas sebelah utara dibatasi dengan kelurahan Jagir

2. Untuk Batas sebelah selatan berbatasan dengan kelurahan Margorejo

3. Untuk batas sebelah timur berbatasan dengan kelurahan Panjang Jiwo

4. Untuk batas sebelah barat berbatasan dengan kelurahan Bendul Merisi

Untuk batas antara Sidosermo dengan Sidoresmo adalah sebuah masjid yang berada ada di tengah-tengah kampung yang mana itu juga menjadi batas wilayah kecamatan Wonokromo dan wilayah Wonocolo di mana sebelah utara dari masjid tersebut masuk wilayah Wonokromo dan sebelah selatan dari masjid tersebut masuk wilayah Wonocolo, seluruh warga kampung di Sidosermo dan Sidoresmo Dalam ini adalah masih memiliki hubungan darah saudara dari satu kakek buyut yang meskipun berada di sebuah kota sekelas Surabaya tetapi memiliki nilai-nilai Islami yang yang masih dipertahankan sampai saat ini, dan itu menjadi sebuah ciri yang khusus yang dimiliki oleh Kampung ini. 35

Kampung Sidosermo merupakan kampung yang sarat akan sejarah dan cerita. Pada zaman dahulu, kampung ini

35 Fatimatuz Zahro and Parmin, "Kampung Sidosermo: Kampung Pesantren di Kota Metropolitan," Surya.Co.Id, April 14, 2017, https://surabaya.tribunnews.com/2017/04/16/kampung-sidosermokampung-pesantren-di-kota-metropolitan. 
merupakan pusat aktivitas keagamaan di kota Surabaya dikarenakan pendiri dari kampung ini adalah murid dari Sunan Ampel, sehingga mayoritas warganya merupakan keturunan dari orang yang ahli di bidang agama. Nama istilah "Dalam" berasal dari bahasa Jawa yang berarti rumah seorang Kyai.

Kampung Sidosermo termasuk kampung tertua yang ada di Surabaya. Sejarah dari Kampung Sidosermo berasal dari seorang putra dari Sunan Gunung Jati di Jawa Barat, bahwa Sunan Gunung Jati juga menikah dengan seorang pribumi di tanah Jawa dan juga memiliki seorang istri dari negeri Campa atau sekarang dikenal dengan Kamboja. Pernikahan ini melahirkan dua Putra bersaudara yang dikenal dengan Syekh Arif dan Syekh Sulaiman kemudian kedua putra dari Sunan Gunung Jati ini berkelana dan mencari ilmu hingga sampai di di Jawa Timur tepatnya di daerah Pasuruan.

Kemudian Syekh Sulaiman diminta oleh keraton Mataram di Jawa Tengah untuk menjadi seorang Patih atau menjadi seorang penasehat namun Syekh Sulaiman sendiri bimbang antara menerima ataupun menolak sehingga beliau berdoa jika memang menjadi hal yang baik maka dia rela menjadi seorang Patih atau penasehat tapi jika menjadi hal yang buruk, maka lebih baik saya Sulaiman tidak sampai kerajaan Mataram. Dalam perjalanannya dari Pasuruan menuju ke Mataram Syekh Sulaiman meninggal di dalam perjalanannya di suatu daerah bernama Mojoagung yang sekarang berada di Kabupaten Jombang. Ada yang mengatakan bahwa ketika dimintai untuk menjadi seorang penasehat atau bupati beliau Syekh Sulaiman meminta izin kepada orang tuanya yang berada di Cirebon namun ketika di tengah perjalanan Syekh Sulaiman sakit dan meninggal di daerah Jombang atau tepatnya di daerah Mojoagung.

Ketika di Pasuruan Sayyid Sulaiman atau Syekh Sulaiman dinikahkan dengan seorang putri dari Mbah sholeh Semendi Pasuruan, yang kemudian lahirlah seorang putra bernama Ali Akbar yang menjadi sebuah cikal bakal akan lahirnya Kampung Sidosermo ini. Sayyid Ali Akbar berguru kepada kepada murid atau keturunan dari Sunan Ampel. 
Pada suatu malam terjadi sebuah cerita dimana Sunan Ampel atau mungkin pengasuh dari pondok pesantren Sunan Ampel itu berjalan-jalan melihat para santri yang sedang tertidur namun ada 1 santri yang berbeda yaitu Sayyid Ali Akbar, dia memiliki cahaya terang dari tubuhnya yang kemudian diberi tanda dengan seikat tali oleh pengasuh dari Pondok Sunan Ampel. Pada pagi harinya ditanya oleh pengasuh dari Sunan Ampel ini siapa yang kakinya terdapat ikatan tali. Pada mulanya tidak ada yang berani untuk menjawab namun pada akhirnya ketahuan bahwa Syekh Ali Akbar lah yang terdapat ikatan tali.36

Kepintaran dan keahlian dari seorang Sayyid Ali Akbar ini sudah sangat tidak diragukan lagi sehingga pengasuh dari Sunan Ampel atau keluarga dari Sunan Ampel meminta untuk Sayyid Ali Akbar membuat pesantren sendiri dengan lima murid atau lima Santri yang kemudian Syekh Ali Akbar ini membuka lahan di daerah yang sekarang namanya adalah Sidosermo. Nama ini berasal dari lima santri dari Sayyid Ali Akbar ini yang yang selalu mengaji bersama dalam istilah Jawanya nderes sehingga disebut ndresmo atau singkatan deres santri limo (lima murid sedang mengaji) atau biasanya disebut dengan Sidosermo yang artinya sido nderes santri limo (lima santri jadi mengaji).37

Keadaan ekonomi dan sosial di kampung Sidosermo tak lepas dari keadaan ekonomi dan sosial di Surabaya dan bahkan di Indonesia. Indonesia yang pada saat ini sudah menjadi negara yang lebih demokratif dan lebih berkembang dalam ilmu pengetahuan teknologi dan sosialnya juga turut memberikan sumbangsih perubahan di Kampung Sidosermo ini namun sebuah ciri khas tetap menjadi sebuah hal yang dominan ada di kampung ini. Keadaan sosial di Sidosermo yang demokratis bisa terlihat dengan diselenggarakannya pemilihan ketua RT, ketua RW dan pemilihan lurah dengan sistem musyawarah secara demokratis.

\footnotetext{
36 Linda Ainur Rohmah, "Perjuangan Kiai Mas Cholil Untuk Memperoleh Status Tanah Perdikan dari Pemerintah Kolonial Belanda di Sidoresmo Surabaya" (UIN Sunan Ampel Surabaya, 2018), 30.

37 "Kampung Sidosermo, Sebuah Peradaban di Surabaya yang Masih Eksis," 2020, https://www.ngopibareng.id/timeline/kampung-sidosermo-sebuahperadaban-di-surabaya-yang-masih-eksis-1452072.
} 
Dari segi ekonomi, pada umumnya profesi warga Sidosermo adalah menjadi pengajar, pengusaha atau guru ngaji. Karena mayoritas warga berprofesi sebagai guru ngaji maka pemerintah Hindia Belanda pada waktu penjajahan menghibahkan tanah dan sampai sekarang status tanah di kampung Sidosermo adalah bebas pajak.38

Dalam kegiatan pendidikan formal, di Kampung Sidosermo terdapat Paud, Taman Kanak-kanak (TK), Madrasah Tsanawiyah, Madrasah Aliyah dan pondok-pondok kecil berupa TPA (Taman Pendidikan Al-Qur'an) untuk menghafal al-Qur'an dan beberapa pondok pesantren.39

\section{Ijbar Nikah di Desa Sidosermo Dalam Wonokromo Surabaya}

Berkaitan dengan praktik ijbar nikah di Desa Sidosermo Kelurahan Jagir Kecamatan Wonokromo, peneliti mengambil 4 orang yang melaksanakan perkawinan sebab adanya paksaan dari orang tua. Selain itu terdapat hasil wawancara dengan warga Sidosermo terkait pandangan mereka tentang ijbar nikah. Berikut hasil wawancara dengan beberapa orang yang dipaksa nikah:

1. Bunga (bukan nama sebenarnya)

Bunga (24 Tahun) adalah lulusan salah satu Universitas Negeri terbaik di Surabaya putri dari bapak Budi (bukan nama sebenarnya) dan suaminya bernama Anton (27 tahun) putra dari Bapak Mudaji (bukan nama sebenarnya). Mereka melangsungkan pernikahan pada tahun 2012 dan hasil wawancara dengan Bunga adalah sebagai berikut:

Pernikahan kami digelar dengan sangat mewah. Pada saat itu pernikahan ini dilakukan atas dasar wasiat dari abah saya, yang sebelum meninggal memberikan wasiat bahwa ada salah satu di antara putra atau putrinya yang dinikahkan dengan putra atau putri dari Mas Mudaji, adik dari umi saya. Pada saat itu saya adalah anak terakhir yang sudah tidak ada lagi putra atau putri dari abah saya, sehingga saya adalah opsi

38 Ibid., 8.

39 Ibid., 54 
Ijbar Nikah di Kampung Sidoserma Dalam...

terakhir dan opsi utama di dalam pernikahan ini, untuk menyambung hubungan keluarga. Atas dasar wasiat ini lah kami melangsungkan pernikahan.40

2. Adi (bukan nama sebenarnya)

Adi adalah alumni UIN Sunan Ampel Surabaya, putra dari KH. Mas Marijan yang berpasangan dengan saudari Intan (bukan nama sebenarnya putri dari H. Mas R. Mereka melangsungkan pernikahan pada tahun 2016. Hasil wawancara mengenai proses pernikahan mereka adalah sebagai berikut:

Kami menikah pada tahun 2016 lalu, di mana sebenarnya saya sudah memiliki seorang wanita yang saya anggap sebagai calon istri saya, tetapi Abah berkata lain dan menjodohkan saya dengan putri seorang Kyai Pondok Pesantren yang bernama Intan yang menjadi istri saya saat ini. Pernikahan ini memang menjadi sebuah harapan besar dari kedua belah pihak keluarga kami. Di kampung ini terdapat banyak Pondok Pesantren termasuk pondok pesantren Abah saya dan pondok pesantren dari keluarga istri saya, sehingga pernikahan ini menjadi sebuah hubungan penyambung diantara dua keluarga besar ini. Bagaimanapun usaha saya untuk menolak, Abah tetap tegas terhadap maksudnya untuk menikahkan saya dengan calon pilihan Abah dan saya sebagai seorang anak hanya bisa pasrah takut akan ketidak keridhoan dari orang tua saya. 41

3. ILN

ILN (22 tahun) alumni pondok pesantren Langitan Widang Tuban dijodohkan dengan AH (27 tahun) alumni pondok pesantren Lebak Pasuruan. Mereka melangsungkan pernikahan pada tahun 2017 dan sudah dikaruniai 1 orang anak. Berikut adalah wawancara dengan ILN:

Pada saat itu saya masih di pondok pesantren dan belum selesai menempuh studi di sana, tetapi orang tua

40 Bunga, Wawancara, Surabaya, 24 April 2020.

41 Adi, Wawancara, Surabaya, 20 April 2020. 
saya supaya saya pulang dan dinikahkan dengan suami saya saat ini. Sebenarnya pada waktu itu saya masih belum siap untuk menjalani sebuah pernikahan tapi orang tua selalu memaksa saya untuk melaksanakan pernikahan. Alasannya adalah sederhana mereka berpikir dengan siapa lagi saya akan menikah, karena takut maka saya terpaksa melangsungkan pernikahan ini.42

4. Andika (bukan nama sebenarnnya)

Andika (27 tahun) adalah putra dari Mas Bayu (bukan nama sebenarnya) yang dijodohkan dengan AP (21 tahun) putri dari K H Bagas (bukan nama sebenarnya), berikut adalah hasil wawancara dengannya:

Sedianya saya akan menikah bulan depan dengan seorang wanita yang bukan pilihan saya. Saya mempunyai seorang kekasih namun orang tua tidak memberikan izin pada saya untuk menikahinya dikarenakan sebuah mitos yang berkembang di daerah saya bahwa jika warga Kampung kami menikah dengan warga Kampung tertentu hal itu akan menjadi sebuah sesuatu yang buruk karena sudah disumpah oleh nenek moyang kami, sehingga orang tua saya menjodohkan dengan wanita pilihannya.43

Pendapat masyarakat Sidosermo terhadap ijbar nikah:

1. Muhammad Fahmi

Dalam hal ini beliau berkata:

Saya tidak masalah dengan ijbar nikah, karena orang tua itu pasti tidak akan pernah menginginkan anaknya untuk terjerumus ke dalam sebuah hal yang buruk. Hal itu jelas menjadi sebuah pertimbangan oleh orang tua dari calon mempelai yang terkadang tidak selalu dipahami oleh putra atau putri dari orang tersebut.44

2. KH Mas Mudzoffar

Menurut KH Mas Mudzoffar:

42 ILN, Wawancara, Surabaya, 20 April 2020.

43 Andika, Wawancara, Surabaya, 1 Mei 2020.

44 Muhammad Fahmi, Wawancara, Surabaya, 2 Mei 2020. 
Dalam ijbar nikah sebenarnya sudah memenuhi syarat di dalam hukum fikih karena menurut pendapat Mazhab Syafi'i pernikahan paksa itu boleh untuk dilakukan meskipun kepada seorang gadis yang sudah dewasa. Saya yakin orang tua yang menikahkan putrinya atau putranya secara paksa sudah memenuhi syarat-syarat nikah yang sudah ditentukan oleh Imam Syafi'i, sehingga dalam hal ini pernikahan paksa menjadi sebuah hal yang tidak melanggar hukum Islam. 45

\section{Analisis Hukum Islam terhadap Ijbar Nikah di Kampung Sidosermo Dalam Surabaya}

Berdasarkan data di atas diketahui bahwa ada beberapa faktor penyebab terjadinya pernikahan paksa, padahal anak yang dipaksa menikah sudah dikatakan mencapai usia dewasa menurut undang-undang dan dikatakan dewasa ataupun baligh menurut hukum fikih Islam:

1. Kekhawatiran akan masa depan anak

Terkadang sebagai seorang tua memiliki rasa khawatir apabila putrinya yang sudah memasuki usia layak nikah tetapi masih belum mendapatkan calon atau masih belum mendapatkan suami.46 Hal ini menjadikan orang tua menempuh jalan paksa untuk menikahkan orang anak tersebut.

Orang tua menganggap bahwa calon mempelai yang dijodohkan dengan anaknya dianggap memiliki kapabilitas yang cukup dan mumpuni untuk menjadi seorang pendamping anaknya, yang nantinya dapat menuntun masa depan keluarga yang diharapkan menjadi sebagai keluarga yang sejahtera dan mapan. 47

2. Hubungan kekeluargaan

Hubungan kekeluargaan menjadi sebuah salah satu faktor terjadinya ijbar nikah di daerah Sidosermo. Hal ini

45 KH Mas Mudzoffar, Wawancara, Surabaya, 2 Mei 2020.

46 ILN, Wawancara, Surabaya, 20 April 2020.

47 Fahmi, Wawancara, Surabaya, 2 Mei 2020 
biasanya terjadi dikarenakan adanya hubungan kekeluargaan yang jauh antara calon mempelai laki-laki dan calon mempelai perempuan. Dengan pernikahan paksa ini orang tua mengharapkan hubungan kekeluargaan tersebut menjadi dekat kembali.

Hal tersebut tidak lepas dari keadaan Kampung Sidosermo yang kebanyakan warganya masih memiliki ikatan darah atau ikatan kekeluargaan dari pendiri kampung Sidosermo yaitu Sayyid Ali Akbar. Karena itu, beberapa keluarga ingin menyambung tali kekeluargaan tersebut dengan jalur pernikahan sehingga terkadang semenjak kecil sudah terdapat wacana untuk pernikahan anak ketiga dari keluarga si A dengan anak ke-4 atau ke-5 dari keluarga si B dan beberapa contoh kasus lainnya.

Faktor hubungan kekeluargaan ini juga didasarkan pada pemikiran bahwa mereka memiliki derajat atau kafaah yang sama, sehingga disayangkan andaikata si anak atau calon mempelai ini dinikahkan dengan orang lain yang belum tentu memiliki kesamaan dalam derajat. 48

3. Pemahaman fikih Syafi'i yang membolehkan ijbar nikah

Pemahaman hukum Islam di Sidosermo kental dengan mazhab Syafi'i. Dalam pendapat mazhab Syafi'i, seorang ayah boleh memaksa anaknya untuk menikah, meskipun sudah dewasa dengan syarat-syarat tertentu. Pemaksaan pernikahan menjadi sebuah hal yang lumrah dan wajar sehingga orang tua merasa memiliki tanggung jawab untuk menentukan dan memilih calon pendamping hidup yang dianggap sebagai seseorang yang memiliki kapasitas. 49

4. Wasiat

Ijbar nikah dilakukan karena adanya wasiat dari orang tua, sebagaimana pernikahan Bunga. 50

5. Mitos

Faktor lain ijbar nikah di desa Sidosermo adalah dikarenakan adanya sebuah ketidakcocokan dengan calon

48 Adi, Wawancara, Surabaya, 20 April 2020.

49 KH Mas Mudzoffar, Wawancara, Surabaya, 2 Mei 2020.

50 Bunga, Wawancara, Surabaya, 24 April 2020 
yang diajukan oleh anak karena faktor mitos dan pamali. Di antara mitos tersebut adalah tentang adanya larangan pernikahan antara warga Sidosermo dengan daerah tertentu, jika dilanggar maka akan terjadi sesuatu yang negatif.51 Selain itu terdapat larangan menikah dengan calon mempelai dari keturunan orang yang pernah menjadi musuh dari pendiri dan sesepuh Kampung Sidosermo. Karena itu anak dijodohkan agar tidak terjadi pernikahan yang dilarang tersebut.

Berdasarkan faktor di atas, maka praktik ijbar nikah masih berlangsung di kampung Sidosermo. Dalam praktik ijbar nikah ini tidak lepas dari peran orang tua selaku wali dari mempelai. Wali memang menjadi syarat dalam sebuah pernikahan menurut mayoritas mazhab fikih, hanya imam Hanafi yang memperbolehkan pernikahan tanpa wali, itu juga dengan syarat calon mempelai adalah seorang janda. Dalam ijbar nikah, wali yang memaksa putra atau putrinya untuk melangsungkan sebuah pernikahan dalam istilah fikih disebut sebagai wali mujbir

Istilah wali mujbir dimaknai dengan orang tua yang memaksa anaknya untuk kawin atau menikah dengan pilihannya, bukan pilihan anaknya. Maka dalam masyarakat kita muncullah istilah "kawin paksa" atau memiliki konotasi ikrah dan ijbar. Ijbar tidak sama dengan ikrah. Ijbar seorang ayah lebih bersifat tanggung jawab belaka, dengan asumsi bahwa anak perempuannya belum memiliki kemampuan untuk bertindak sendiri. Dalam Mazhab Shafi'i, istilah ijbar dikaitkan dengan beberapa syarat, antara lain:

1. Tidak ada permusuhan (kebencian) perempuan itu dengan laki-laki calon suaminya.

2. Tidak ada permusuhan (kebencian) perempuan itu kepada ayahnya.

3. Calon suami haruslah orang yang sekufu/ setingkat/sebanding.

51 Andika, Wawancara, Surabaya, 1 Mei 2020. 
4. Mahar (mas kawin) harus tidak kurang dari mahar mitsil, yakni mas kawin perempuan lain yang setara.

5. Calon suami diperkirakan tidak akan melakukan perbuatan/tindakan yang akan menyakiti hati perempuan itu.

Dalam Mazhab Shafi'i, orang tua boleh menikahkan anak perawannya apabila pernikahan itu menguntungkannya atau tidak merugikan dirinya. Dalam kitab Kifāyah al-Akhyār dijelaskan bahwa izin dari seorang gadis perempuan dewasa jika yang menikahkan selain ayah dan kakek adalah sebuah keharusan. Ini artinya wali selain ayah atau kakek tidak bisa menikahkan tanpa persetujuan dari si gadis tersebut. Hal ini sebagaimana yang dipahami dari ibarah di bawah ini:

Apabila yang menikahkan (gadis) selain bapak dan kakeknya maka harus mendapatkan izin si gadis setelah balig (dewasa)" 52

Dalam masalah ijbar ini, menurut Mazhab Maliki, Shafi'i, dan Hambali, seorang gadis meski sudah dewasa tetapi belum pernah menikah, maka hak ijbar boleh diterapkan. Menurut mazhab Hanafi seorang anak sudah dewasa, baik masih perawan atau janda, hak ijbar dari ayah sudah tidak lagi boleh diterapkan.

Perbedaan pendapat ulama mazhab tentang ijbar ini karena adanya pemahaman yang berbeda terhadap hadis berikut:

Diriwayatkan dari Ibnu Abbas bahwasanya Nabi Muhammad SAW bersabda: Tidak berhak bagi seorang wali memerintah seorang janda untuk menikah, dan gadis dewasa dimintakan persetujuannya, dan diamnya adalah sebuah penerimaan. 53

Nabi Muhammad SAW bersabda, seorang janda lebih berhak atas dirinya daripada seorang walinya, sedangkan

52 Taqiyuddin Al-Ḥusain̄̄ Kifāyah al-Akhyār Fi Hall Ghāyah al-Ikhtiṣār, Juz II (Surabaya: Dār al-Ilm, t.t.), 45.

53 Al-Munāwī, Faidh al-Qadīr Sharh 'ala al-Jāmi' Al-Ṣaghīr, 379. 
seorang perawan dimintakan persetujuan, diamnya adalah bentuk izinnya. 54

Perwalian laki-laki terhadap perempuan dalam hal pernikahan merupakan mekanisme sosial untuk memberikan perlindungan. Mandat utama sebagai laki-laki adalah memastikan anak perwaliannya memperoleh calon pengantin yang terbaik, setara, dan sesuai dengan cita maslahah keluarga yaitu mewujudkan keluarga yang sakīnah, mawaddah wa rahmah.55

Ijbar nikah di Sidosermo tidak hanya terjadi pada anak perempuan tetapi juga pada anak laki-laki. Dilihat dari data narasumber, dari segi usia mereka sudah masuk kategori dewasa ketika terjadi perkawinan tersebut. Sehingga dari hukum Islam, mereka berhak menentukan dan memilih pasangannya sendiri. Namun karena beberapa faktor, akhirnya mereka memilih menikah dengan pasangan yang ditentukan oleh keluarganya.

Keberlangsungan praktik ijbar ini tidak lepas dari budaya dan pemahaman keagamaan di desa Sidosermo, bahwa seorang anak hendaknya taat kepada orang tua di antaranya dalam memilih pasangan suami atau istri, karena keridhoan Allah terdapat dalam keridhoan orang tua. Selain itu konsep kafä'ah juga menjadi dasar penentu orang tua menjodohkan anaknya dalam perkawinan.

Perkawinan yang didasarkan atas persetujuan kedua calon mempelai dijelaskan dalam KHI Pasal 16 yaitu: Perkawinan didasarkan atas persetujuan kedua calon mempelai. Hal tersebut sejalan dengan Undang-undang perkawinan tahun 1974 pasal 6 ayat 1 bahwa perkawinan harus didasarkan atas persetujuan kedua calon mempelai.

Persetujuan calon mempelai mengandung asas kesukarelaan, yang merupakan syarat mutlak perkawinan. Perkawinan merupakan ikatan lahir batin, maka tanpa adanya suatu persetujuan dari kedua calon mempelai, mungkin ikatan

54 Muslim, Saḥih Muslim, hadis nomor 2638.

55 Faqihuddin Abdul Kodir, Qira'ah Mubadalah Tafsir Progresif Untuk Keadilan Gender dalam Islam (Yogyakarta: IRCiSoD, 2019), 362. 
lahir dapat terjadi, akan tetapi ikatan batin belum tentu terjadi. Tujuan perkawinan itu sendiri adalah untuk membentuk keluarga yang bahagia dan kekal berdasarkan Ketuhanan Yang Maha Esa, maka sangat sulit untuk kebahagiaan itu akan tercapai apabila perkawinan tersebut tidak dibentuk berdasarkan suka rela dari kedua calon mempelai.

Peluang adanya kawin paksa dimungkinkan terjadi karena dalam undang-undang perkawinan terdapat pemberian izin dari orang tua kepada anak yang hendak kawin yang belum berusia 21 tahun (pasal 6 ayat (2) dan dalam KHI melalui bentuk persetujuan calon mempelai wanita, yang dikatakan dalam pasal 16 ayat (2), bahwa: "Bentuk persetujuan calon mempelai wanita dapat berupa pernyataan tegas dan nyata dengan tulisan, lisan atau isyarat, tapi dapat juga berupa diam, dalam arti selama tidak ada penolakan yang tegas." 56

Berdasarkan hal tersebut, pernikahan dengan ijbar ini bisa dikatakan sah secara undang-undang, selama tidak ada penolakan yang tegas dari calon mempelai putra atau putri ketika akad berlangsung. Meskipun demikian, dengan kondisi saat ini, hendaknya keluarga tidak memaksakan konsep ijbar dalam pernikahan dan mengakomodir kehendak anaknya untuk menikah dengan pasangan pilihannya selama tidak menyalahi rukun dan syarat perkawinan dalam hukum Islam.

\section{Penutup}

Dari uraian dan data serta analisis yang dilakukan oleh penulis dapat kita simpulkan bahwa ijbar nikah masih terjadi secara masif di Kampung Sidosermo karena beberapa faktor, yaitu: Kekhawatiran orang tua terhadap masa depan anaknya, kedekatan keluarga, pemahaman fikih Syafi'i yang membolehkan ijbar nikah, dan mitos.

Ijbar nikah di Kampung Sidosermo Dalam Surabaya tidak hanya terjadi kepada anak perempuan, namun juga terjadi pada anak lelaki. Ijbar nikah tersebut tidak hanya terjadi pada anakanak tetapi pada perempuan dan laki-laki dewasa (balig).

56 Ratna Batara Munti and Hindun Anisah, Posisi Perempuan dalam Hukum Islam di Indonesia (Jakarta: LBH-APIK, 2005), 60-61. 
Dalam tinjauan hukum Islam, meskipun terdapat mazhab yang membolehkan ijbar nikah dengan syarat-syarat tertentu, namun seharusnya pernikahan terjadi didasarkan sukarela tanpa pemaksaan. Ditinjau dari hukum di Indonesia, pernikahan mengacu pada undang-undang nomor 1 tahun 1974 tentang Perkawinan dan Kompilasi Hukum Islam, yang menyebutkan bahwa syarat dari pernikahan adalah ada persetujuan dari kedua calon mempelai dan apabila tidak ada unsur itu, maka pernikahan tersebut bisa dibatalkan.

Berdasarkan hal tersebut, meskipun ijbar nikah yang terjadi di Kampung Sidosermo tidak menyalahi hukum Islam dan undang-undang perkawinan, namun hendaknya orang tua juga memberikan hak kepada anaknya untuk bisa menentukan pasangan dalam hidupnya.

\section{Daftar Pustaka}

Baghdadi (al), Abdul Wahab Bin Ali. Ishrāf Ala Nuqāt Masā'il alKhilāf. Beirut: Dār Ibn Hazm, 1999.

Bugha (al), Musthafa Dib. Al-Tadzhīb Fi Adillati Matn al-Ghāyah Wa al-Taqrīb. Beirut: Dar Ibn Katsir, 1992.

Bukhari (al). Shahih Al-Bukhari, n.d.

Husaini (al), Taqiyuddin. Kifāyah al-Akhyār Fi Hall Ghāyah AlIkhtisār. Surabaya: Dar al-Ilm, n.d.

Kasān̄̄ (al). Badāi' al-Ṣanāi'. Beirut: Dār al-Iḥya', 1998.

Munāwī (al), Muhammad Abdurrauf. Faidh Al-Qadīr Sharh Ala alJāmi' al-Saghir. Beirut: Dār al-Fikr, 2002.

Nawāwī (al), Yahya bin Sharaf. Minhāj al-Ṭalibin Wa 'Umdah alMuftīn. Beirut: Dār al-Fikr, 1992.

Zuhaily (al), Wahbah. Al-Fiqh Al-Islāmy Wa Adillatuh, Juz VII. Beirut: Dār al-Fikr, 1998.

Cahyadi, Ady. Ady Cahyadi, "Mengelola Hutang dalam Perspektif Islam," ESENSI: Jurnal Bisnis dan Manajemen, Vol. 4, No. 1, Juni, 2014.

Gampito. "Pemikiran Kebijakan Fiskal Ekonomi Islam," Juris: Jurnal Ilmu Syariah, Vol. 9, No. 1, Juni, 2010.

Haq, Husnul. "Reformulasi Hak Ijbar Fiqh dalam Tantangan Isu Gender Kontemporer,” Palastren, Vol. 8 no. 1, Juni, 2015. 
Hidayat, Syaiful. "Hak Ijbar Wali Nikah Dalam Kajian Historis Fiqh Syafi'i." Tafaqquh: Jurnal Penelitian Dan Kajian Keislaman 3, no. 1 (2015): 1-13.

Hidayat, Taufiq. "Rekonstruksi Konsep Ijbar," De Jure, Jurnal Syariah dan Hukum, Vol. I, No. 1, Juni, 2009.

Hidayatulloh, Rohmat. Rohmat Hidayatulloh, "Tradisi Pernikahan dengan Kesetaraan Keturunan dalam Keluarga Para Mas Sidosermo Kecamatan Wonocolo Surabaya dan Berbek Kecamatan Waru Sidoarjo," AlHukama' 7, Vol. 7, No. 1, Juni, 2017.

Ishak. Ishak, "Perwalian Menurut Konsep Hukum Tertulis," Kanun Jurnal Ilmu Hukum, Vol. 19, No. 3, Desember, 2017. Izzati, Arini Robbi. Arini Robbi Izzati, "Kuasa Hak Ijbar Terhadap Anak Perempuan Perspektif Fiqh dan HAM," Al-Mawarid XI, Vol. 11 No. 2 (September-Januari, 2011)

Juabdin, Heru Sada. "Konsep Pembentukan Kepribadian Anak dalam Perspektif Al-Qur'an (Surat Luqman Ayat 12-19)," Al-Tadzkiyyah: Jurnal Pendidikan Islam, Vol. 6, No. 2, November, 2015.

"Kampung Sidosermo, Sebuah Peradaban di Surabaya yang Masih Eksis." 2020.

https://www.ngopibareng.id/timeline/kampungsidosermo-sebuah-peradaban-di-surabaya-yang-masiheksis-1452072.

"Kamus Besar Bahasa Indonesia (KBBI)." https://kbbi.web.id/paksa, n.d.

Kodir, Faqihuddin Abdul. Qira'ah Mubadalah Tafsir Progresif Untuk Keadilan Gender Dalam Islam. Yogyakarta: IRCiSoD, 2019.

Masrur, Muhamad. "Konsep Harta dalam Al-Qur'an dan Hadis," Jurnal Hukum Islam, Vol. 15, No. 1, Juni, 2017.

Munti, Ratna Batara, and Hindun Anisah. Posisi Perempuan dalam Hukum Islam di Indonesia. Jakarta: LBH-APIK, 2005.

Mushalli, Abdullah bin Mahmud. Al-Ikhtiyār Li Ta'dīl Al-Mukhtār. Beirut: Dār al-Ma'rifah, 2002. 
Muttaqin, Muhammad Ngizzul, and Nur Fadhilah. "Hak Ijbar Wali Tinjauan Maqashid Syari'ah dan Antropologi Hukum Islam," Journal de Jure, Vol. 12, No. 1, Juni, 2020. Qudamah, Ibn. Al-Mughni. Kairo: Dār al-Manār, 1999.

- - C. Sharh al-Kabìr. Beirut: Dār al-Fikr, 1998.

Rohmah, Linda Ainur. "Perjuangan Kiai Mas Cholil untuk Memperoleh Status Tanah Perdikan dari Pemerintah Kolonial Belanda di Sidoresmo Surabaya." UIN Sunan Ampel Surabaya, 2018.

Rushd, Ibn. Bidāyah al-Mujtahid Wa Nihāyah Al-Muqtașid. Kairo: Maktabah Ibnu Taimiyah, 1994.

Samsidar. "Dampak Kawin Paksa Terhdapa Kehidupan Rumah Tangga Pada Masyarakat Lamurukung Kabupaten Bone." Supremasi: Jurnal Pemikiran dan Penelitian Ilmu-Ilmu Sosial, Hukum, \& Pengajarannya, Vol. 14, No. 1, April, 2019.

Siddik, Ammar Hasibuan. “Otoritas Orang Tua Dalam Memaksa Kawin Anak Usia 21 Tahun Ditinjau Dari Kompilasi Hukum Islam (Studi Kasus Desa Sibual-Buali. Kec. Ulu Barumun, Kab. Palas)." Universitas Sumatera Utara, 2018.

Yusuf, Moh. "Tinjauan Hukum Islam Terhadap Kawin Paksa Dan Implikasi Hukumnya (Studi Kasus Di Desa Dekat Agung Kecamatan Sangkapura Bawean Kabupaten Gresik)." UIN Sunan Ampel Surabaya, 2016.

Zahro, Fatimatuz, and Parmin. "Kampung Sidosermo: Kampung Pesantren Di Kota Metropolitan.” Surya.Co.Id. April 14, 2017.

https://surabaya.tribunnews.com/2017/04/16/kampu ng-sidosermo-kampung-pesantren-di-kotametropolitan. 